\title{
EXPANDED HOSPITAL LIABILITY UNDER THE FEDERAL FAlse Claims Act: An UneXPECTED Solution to the RESIDENT DUTY HOUR CONTROVERSY
}

\author{
Robert R. Elder ${ }^{*}$
}

\section{TABLE OF CONTENTS}

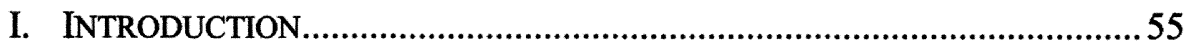

A. Medical Residents: Why We Need Them and Why

They Need Sleep.

B. Duty Hour Restrictions: Attempts to Reduce the

Risks Posed by Chronically Sleep Deprived

Medical Residents

C. A Possible Solution to an Apparently Irresolvable

Conflict.

II. THE MEDICAL RESIDENT DUTY HOUR CONTROVERSY

A. Arguments Made by Proponents of Traditional

Resident Duty Hours

1. The Traditional View: No Rest for Weary Residents

2. The Arguments Made by Proponents of Resident

Duty Hour Reform.

B. Why Duty Hour Restrictions are Necessary for Residents ..........60 60

1. Initial Attempts at Reform via Regulation.

2. The ACGME's Comprehensive Approach to

Oversight: See No Evil, Hear No Evil, and

Speak No Evil.

C. ACGME Duty Hour Standard Enforcement:

Why It Doesn't Work.

1. A Conglomerate of Agencies: Too Many Doctors

Jumping on the Bed

2. ACGME Accreditation: A Carrot and a Stick.

3. The Greatest Weakness: A Lack of Whistleblower

Protection

* J.D. Candidate, 2008, Indiana University School of Law - Indianapolis; M.B.A. Candidate, 2008, Indiana University Kelley School of Business; B.A., 1996, Saint Vincent College, Latrobe, Pennsylvania. I would like to thank Mr. Christopher Campaniolo, J.D., Executive Notes Editor of the Indiana Health Law Review, Volume 4, whose friendship and encouragement made the publication of this Note possible. This Note is dedicated to my wife, Catherine, and my daughters, Mackenzie and Maggie, in the hope that the doctors who treat them will always be well rested. Copyright 2008 by Robert R. Elder. 
D. State and Federal Legislative Attempts to Curtail

Duty Hour Violations.

III. MAKING THE GRADE: CAN GRADUATE MEDICAL EDUCATION WITHSTAND THE ASSAULT OF ACTIONS BROUGHT PURSUANT TO FEDERAL THE FALSE CLAIMS ACT? .71

A. The Importance of Main \& Chapman ....................................... 71

B. The False Claims Act Generally .............................................. 71

1. The Applicability of the False Claims Act ............................ 71

2. Persons Amenable to Suit Under the False Claims Act

3. Knowing Action Under the False Claims Act

4. Bringing a Claim Pursuant to the False Claims Act:

The Qui Tam Suit.

5. Damage Liability Under the False Claims Act

6. Whistleblower Protections Under the False Claims Act.

a. Protection and relief for whistleblowers: Employers beware.

b. Federal jurisdiction: Retaliatory discharge and whistleblower actions.

c. Whistleblower actions: Essential elements and limitations

C. Government Funding of Graduate Medical Education: The Essential Link.

D. The False Claims Act: Expanding Applicability

1. One lie begets another: The chain of causation grows longer

2. A chain attenuated does not break: Reaping what you sow.

IV. EXPANDED LIABILITY UNDER THE FALSE CLAIMS ACT:

IN THE WAKE OF MAIN AND CHAPMAN

A. Expanded Liability of Universities Generally: Why

Hospitals Should Take Note

B. The Expanded Liability of Hospitals with Federally

Funded Graduate Medical Education Programs.

1. Hospital Liability Under the False Claims Act: A Statute Reinterpreted.

2. Whistleblower Protections for Sleepy Residents:

A Dream Come True. 


\section{INTRODUCTION}

\section{A. Medical Residents: Why We Need Them and Why They Need Sleep}

American doctors are born in premedical undergraduate programs, evolve to intellectual adolescence in the crucibles of postgraduate medical schools, and achieve mature self-sufficiency through clinical practice in hospital-based medical residency programs. The relationship between hospitals and medical schools is not, however, as one sided as this simplistic theorem of physician development appears to suggest. Rather, their relationship is a symbiotic one. Medical schools need the endless array of experiential opportunities available in public hospitals to provide medical students with hands-on practice, while public hospitals depend on the faculties of medical schools to educate and supervise their medical residents ("Residents"). ${ }^{1}$ Consequently, in a vast majority of America's public hospitals Residents perform most of the on call, emergency, and neo-natal patient care services. ${ }^{2}$ Residents have similar duties in most private hospitals. ${ }^{3}$ It is not hyperbole, therefore, to suggest that Residents constitute the "lifeblood of most [American hospitals]."

Ironically, however, a hospital's reliance on the unique services rendered by Residents may place the very patients they serve at increased risk. Indeed, it must not be forgotten that Residents are students. As such, they are typically inexperienced and less qualified than more seasoned medical professionals to perform the complex and often life sustaining medical services Residents routinely render. Furthermore, Residents, unlike more experienced doctors, are still attempting to "master, both in theory and in application, the subtle intricacies of human medicine and patient care."5 Moreover, Residents are typically required to work grueling schedules that often result in persistent sleep deprivation and fatigue. ${ }^{6}$ A medical system that is overly reliant on Residents, to pro-

1. W. Paige Hren, Note, Is it the End of an Era or the Beginning of an Error? The American Medical Association Finally Approves Work Hour Limits for Overworked and Sleep Deprived Medical Residents: Should OSHA Still Step In?, 23 J. NAT'L Ass'N ADMIN. L. JUDGES 457, 461 (2003) ("Medical schools need the public hospitals as sites to educate their medical students, and public hospitals need the faculty of medical schools for the education and supervision of their residents." (quoting Stewart R. Reuter, Professional Liability in Postgraduate Medical Education: Who is Liable for Resident Negligence?, 15 J. LEGAL MED. 485, 485 (1994))).

2. Id. at 461-62 ("[I]n most of America's public hospitals, 'residents assume the brunt of 'on call' patient care services."' (quoting Reuter, supra note 1, at 517)).

3. Id. at 462 ("It is also quite common to find residents practicing and learning in private hospitals as well."); $c f$. Reuter, supra note 1, at 517 ("[I]n private hospitals ... senior residents provide most of the care at night, supervised by the patient's physician on call by telephone.").

4. Hren, supra note 1, at 461 ("Residents and residency programs are the life blood of most public hospitals in America.").

5. Id. at 458 .

6. Dori Page Antonetti, Note, A Dose of Their Own Medicine: Why the Federal Government Must Ensure Healthy Working Conditions for Medical Residents and How Reform 
vide patient care, creates obvious risks. Indeed, less experienced chronically sleep deprived Residents may administer inappropriate or inadequate medical services that may result in patient injury or death.

To minimize the risks posed by Resident inexperience, the solution is obvious if not entirely palatable: Residents must learn, and to learn they must practice under the guidance of their more experienced peers in the unique environment afforded by America's hospitals. Consequently, the risks posed by Resident inexperience must be balanced against the nation's need to constantly replenish the supply of highly skilled doctors. Thus, one might argue that the reliance of hospitals on inexperienced Residents is unavoidable and, given proper oversight protocols, excusable. A system that promotes chronic sleep deprivation among Residents, however, is not as easily excused. Such a system is especially problematic when Residents are expected to serve as the vanguard of patient care in America's hospitals.

\section{B. Duty Hour Restrictions: Attempts to Reduce the Risks Posed by Chroni- cally Sleep Deprived Medical Residents}

There have been attempts to improve patient safety by restricting the duty hours of Residents. These attempts, however, have only been marginally successful. This is due in part to the entrenched medical establishment which firmly opposes any external regulation of medical education. ${ }^{7}$ Ironically, reformers' attempts to change Resident duty hours have most often been thwarted by wellmeaning medical educators' intent on preserving the sanctity of the age-old master apprentice educational model ${ }^{8}$ Indeed, lacking what they consider firm "empirical evidence" physicians, teaching in hospitals with residency programs, simply refuse to give up their control over the hours worked by Residents. ${ }^{9}$ As a result, a variety of special interest groups petitioned the federal government to

Should Be Accomplished, 51 CATH. U. L. REV. 875, 876 (2002) ("[F]atigue [is] a condition prevalent among physicians-in-training who commonly work sixty to one hundred and thirty hours per week, with uninterrupted shifts of thirty-six hours or more." (citing HEALTH RES. GROUP, Public Citizen, Publ'n No. 1570, Petition to the Occupational Safety and Health administration ReQuesting that Limits Be Placed on Hours Worked by Medical RESIDENTS (2001), www.citizen.org/publications/print_release.cfm?ID $=6771$ [hereinafter PETITION To OSHA] (last visited Apr. 9, 2008)).

7. Jennifer F. Whetsell, Changing the Law, Changing the Culture: Rethinking the "Sleepy Resident" Problem, 12 AnNals Health L. 23, 63 (2003) ("Some doctors ... vowed not to honor regulations from the beginning, purportedly believing in their hearts that the changes would lead to detrimental effects on patients, including lost information from the discontinuity in care provided to those patients.").

8. Id. at 63 ("[Resident] work hours are what healthcare provider institutions object to most voraciously; they still adhere to the master-apprentice model and thus favor the notion of adequate supervision, at least in theory, if not in practice.").

9. Id. at 64 (" $[\mathrm{P}]$ hysicians exercise a great deal of control over healthcare delivery and they simply do not want to be told what to do, particularly in the absence of what they deem solid empirical findings that contradict their healthcare philosophy."). 
impose Resident duty hour regulations through the agency of the Occupational Safety and Health Administration ("OSHA"). ${ }^{10}$

Proponents of Resident duty hour reform believe that federal oversight would improve Resident working conditions for two reasons: First, federal oversight would dilute the absolute authority that medical educators and hospital administrators wield over Residents. Second, direct federal oversight could provide whistleblower protections that would encourage Residents to report duty hour violations themselves. To date, however, OSHA has formally declined to impose federal oversight over Resident duty hour limitations, choosing instead to adopt standards drafted by the Accreditation Counsel for Graduate Medical Education ("ACGME"). 11

Although well intentioned, the ACGME restrictions on Resident duty hours have been only marginally successful in curtailing the medical community's habit of requiring Residents to work dangerously long duty hours. ${ }^{12}$ The limited success of the ACGME is partially due to the intimate relationship between teaching hospitals and the ACGME. Unlike OSHA, the ACGME is a private regulatory agency composed of special interest groups from the medical community. ${ }^{13}$ As a result, the ACGME mainly consists of career medical professionals and educators intent on preserving the status quo. Thus, its supervisory role not withstanding, the ACGME has proven itself a force to be reckoned with when attempting to reform the practice of medicine in the United States. ${ }^{14}$ Furthermore, the ACGME has a very clear interest in preserving its control over Graduate Medical Education ("GME") because it acts as the sole agency responsible for certifying and accrediting all medical programs in the United States. Not surprisingly, therefore, any mention of whistleblower protections is

10. PETITION To OSHA, supra note 6.

11. Michael J. Frank, Safeguarding the Consciences of Hospitals and Health Care Personnel: How the Graduate Medical Education Guidelines Demonstrate a Continued Need for Protective Jurisprudence and Legislation, 41 ST. LouIs U. L.J. 311, 321 (1996)

The ACGME operates as an unincorporated, 'nonprofit, private association which surveys, evaluates and accredits medical and surgical residency programs throughout the United States.' However, its status as a private institution is somewhat attenuated by the fact that the federal and state governments rely on the ACGME's evaluation of residency programs to determine whether a hospital merits public funding.

(quoting Interfaith Med. Ctr. v. Sabiston, 527 N.Y.S.2d 48, 49 (N.Y. App. Div. 1988)); see, e.g., Changes in Payment Policy for Direct Graduate Medical Education Costs, 54 Fed. Reg. 40,286 (Sept. 29, 1989) (to be codified at 12 C.F.R. pt. 405, 412-13).

12. Robert Neil Wilkey, Federal Whistleblower Protection: A Means to Enforcing Maximum-Hour Legislation for Medical Residents, 30 WM. MrTCHELL L. REV. 331, 342 (2003) ("Despite the breath and thoroughness of these standards substantial evidence suggests that the ACGME has failed to effectively enforce such measures.").

13. Id.

14. Laura Lin \& Bryan A. Liang, Reforming Residency: Modernizing Resident Education and Training to Promote Quality and Safety in Healthcare, 38 J. HEALTH L. 203, 208-09 (2005) (citing ACCREDITATION COUNCIL FOR GRADUATE MED. EDUC., THE ROLE OF THE ACGME (2007), http://www.acgme.org/acWebsite/about/ab_roleACGME.asp [hereinafter THE ROLE] (last visited Apr. 9, 2008)). 
conspicuously absent from the ACGME duty hour standards. As a result, the standards are seen as weak and ineffectual and Residents have little motivation to report violations of the standards. ${ }^{15}$ Consequently, many Residents who are required to work duty hours, in violation of the guidelines imposed by the ACGME, are unwilling to blow the whistle on their employers.

\section{A Possible Solution to an Apparently Irresolvable Conflict}

In response to the ineffectual nature of ACGME oversight and the continued prevalence of Resident duty hour violations, members of the federal legislature backed by prominent groups such as the American Medical Student Association ("AMSA") have attempted to pass legislation that federalizing oversight of hospital duty hours. ${ }^{16}$ Other legislation efforts have sought to provide the whistleblower protections necessary to ensure compliance with the duty hour limitations ostensibly imposed by the ACGME. ${ }^{17}$ Unfortunately, all such legislation has stalled in committee. ${ }^{18}$ Recent rulings in the Seventh and Ninth Circuits, regarding the applicability of the False Claims Act ("FCA"), to federally funded institutions, however, may make future legislation unnecessary. Indeed, it is the contention of this Note that the ruling of the court in United States ex rel. Main v. Oakland City University, ${ }^{19}$ as interpreted and expanded by the court in United States $v$. Chapman University, ${ }^{20}$ has provided proponents of Resident duty hour reform with the legal tools necessary to ensure hospital compliance with the current ACGME duty hour standards.

15. Wilkey, supra note 12 , at 343 ("[T] practitioners as 'weak, voluntary, and different for each specialty' .... [t] thus, the very culture of the medical profession promulgates a perception of the standards as superficial, amendable, and rarely enforceable.") (quoting Sidney M. Wolfe, Public Citizen Petitions to OSHA to Limit Residents' Working Hours, Health Letter, June 1, 2001, http://www.citizen.org/publications/ release.cfm?ID=7222 (discussing work hour limits for Residents under ACGME) (last visited Apr. 9, 2008)).

16. Whetsell, supra note 7, at 57.

17. Id. See, e.g., H.R. 3236, 107th Cong. \$3(c) (2001).

18. Whetsell, supra note 7, at 58 (quoting Damon Adams, Push to Improve Patient Safety Slowgoing, AM. MED. NEws, May 7, 2001, at 1).

19. United States ex rel. Main v. Oakland City Univ., 426 F.3d 914, 916 (7th Cir. 2005), cert. denied, 126 S.Ct. 1786 (2006).

20. United States v. Chapman Univ., No. SACV 04-1256JVSRCX, 2006 WL 1562231, at *2 (9th Cir. May 23, 2006). 


\section{THE MEDICAL RESIDENT DUTY HOUR CONTROVERSY}

\section{A. Arguments Made by Proponents of Traditional Resident Duty Hours}

\section{The Traditional View: No Rest for Weary Residents}

Traditionally, medical practitioners and hospital hierarchies have argued that Residents must work grueling hours. Indeed, proponents assert that such a work schedule is necessary to ensure that Residents observe and participate in all aspects of their patients' illness, treatment, and recovery. ${ }^{21}$ Furthermore, these opponents also point out that grueling duty schedules permit Residents to remain with a patient throughout the patient's stay in the hospital; thereby, avoiding potentially catastrophic gaps in treatment and demonstrating an adequate standard of care. ${ }^{22}$

\section{The Arguments Made by Proponents of Resident Duty Hour Reform}

Conversely, proponents of duty hour reform argue that the long duty hours imposed upon Residents are counterproductive. Proponents typically propose two arguments in favor of reform: First, they assert that working such long hours is likely to result in sleep deprivation that hinders the learning process and is ultimately counterproductive to the broader goals of GME. ${ }^{23}$ Second, proponents argue that Residents who are required to work ridiculously long hours are unlikely to provide care sufficient to meet patients' needs, a deficit likely to place both Residents and patients at increased risk. ${ }^{24}$ To support these arguments, proponents cite studies reporting that Residents working long hours frequently suffer from depression and fatigue conditions known to increase incidents of Resident error resulting in personal and patient injury. ${ }^{25}$

During the 1990's medical studies and improvements in Resident monitoring techniques made it easier for governmental agencies to link iatrogenic

21. Lindsay Evans, Note, Regulatory and Legislative Attempts at Limiting Medical Resident Work Hours, 23 J. LEGAL MED. 251, 252 (2002) ("[L]ong hours are essential to medical education in that proper training requires residents to observe a condition from beginning to end, whenever possible." (citing David A. Asch \& Ruth M. Parker, The Libby Zion Case: One Step Forward or Two Steps Backward?, 318 NEW ENG. J. MED. 771, 774 (1988))).

22. Id. at 252 ("[A]n adequate standard of care requires a resident to stay with his or her patient for the duration of the visit in an effort to preclude dangerous gaps in care and/or information created by frequent shift changes.").

23. Hren, supra note 1, at 459 ("[T] he long hours and resulting sleep deprivation endured by residents are counter productive to the learning process and actually hinder the educational goals of residency training programs.").

24. Id. (" $[\mathrm{N}]$ ot only do the long hours prevent residents from providing adequate patient care, they also pose serious health and safety risks to residents and patients alike.").

25. See, e.g., PETITION TO OSHA, supra note 6. 
injuries to fatigued Resident care givers, a link long suspected by the public. ${ }^{26}$ This increased awareness sparked a revolution in public thought and action, a revolution that persists to this day. As a result, elected officials, patient advocacy groups, and several prominent medical professionals have begun to challenge the authority traditionally accorded teaching physicians and hospital managers who seek to downplay or justify the risks posed by overworked Residents.

\section{B. Why Duty Hour Restrictions are Necessary for Residents}

Inarguably, members of the AMSA are uniquely qualified to offer insight into the risks created by unreasonable Resident duty hours. The position taken by the AMSA is clear: Chronic sleep deprivation unnecessarily increases the risk that Residents will make potentially life threatening medical errors. ${ }^{27}$ In 2004, the New England Journal of Medicine published statistical support for this position in a study that compared the effects of traditional long duty hour and non-traditional short duty hour Resident work schedules. ${ }^{28}$

The study conclusively demonstrated that interns and Residents working on a traditional schedule exhibited an "increased incidence of attentional failures [sufficient to] . . impede their ability to care for patients . . ." 29 Interns working traditional extended shifts were thirty-six percent more likely to make serious medical errors than were those students working shorter shifts. ${ }^{30}$ Residents were also routinely required to remain long after the termination of their shift simply because hospitals habitually failed to ensure that other qualified caregivers would be available for relief, a situation that only aggravated the effects of sleep deprivation. ${ }^{31}$ Finally, scheduling issues aside, the study concluded that nearly a quarter of all Residents might, by natural disposition, be uniquely susceptible to the deleterious effects of chronic sleep deprivation. ${ }^{32}$ Clearly, the intuition of the AMSA was correct. Reform in Resident's duty

26. Thomas R. McLean, The 80-Hour Work Week: Why Safer Patient Care Will Mean More Health Care is Provided by Physician Extenders, 26 J. LEGAL MED. 339, 346 (2005) ("During the 1990's, as the public increasingly became empowered to challenge the authority traditionally accorded physicians, governmental agencies found it easier to link iatrogenic injuries to fatigued health care providers.").

27. Press Release, Kim Becker, Dir. of Pub. Relations, Am. Med. Student Ass'n, New England Journal Reports Medical Errors Relat [sic] to Work Hours: Validates AMSA'S Call for Federal Regulations (Oct. 27, 2004), http://www.amsa.org/news/release2.cfx?id=190 [hereinafter AMA Reports Errors] (last visited Apr. 9, 2008).

28. See generally Steven W. Lockley et al., Effect of Reducing Interns' Weekly Work Hours on Sleep and Attentional Failures, 351 NEw ENG. J. MED. 1829, 1829-33 (2004) (examining the differential impact of long and short duty hour rotations on Residents and provides empirical support for the AMSA's assertion that long duty hours lead to reduced Resident efficiency and reliability.).

29. Id. at 1835 .

30. AMA Reports Errors, supra note 27.

31 . Lockley et al., supra note 28 , at 1836 .

32. Id. 
hour requirements is necessary to promote the safety and well being of Residents and patients alike.

\section{Initial Attempts at Reform via Regulation}

Recognizing that hospitals with medical residency programs typically demonstrate a stubborn unwillingness to voluntarily reduce Resident duty hours, proponents of Resident duty hour reform initially approached the American Medical Association ("AMA") and the ACGME for assistance. 33 These organizations, however, were also initially unwilling to address the issue of Resident duty hour restrictions. Consequently, in 2001, proponents of Resident work hour reform sought federal intervention by asking OSHA to address the issue. $^{34}$ Ironically, the threat of possible federal oversight sparked a flurry of private regulatory action on the part of both the AMA and ACGME. ${ }^{35}$ Thus, in June 2002, "for the first time in history" the AMA adopted policy guidelines aimed at changing the working conditions of medical residents. ${ }^{36}$ Shortly thereafter, the ACGME followed suit by creating Resident duty hour guidelines mirroring those outlined by the AMA. ${ }^{37}$

Ultimately, OSHA declined to adopt a direct role in the creation of Resident duty hour guidelines, opting instead to "rely on the work hour guidelines and enforcement processes recently drafted by the ACGME.",38 OSHA rationalized its decision to rely on the ACGME's Resident work hour guidelines stating that "resident work hour issues would be better addressed by entities with experience both in patient care and employee health. Thus, because the ACGME has extensive experience in patient health, employee health, and medical education and training . . . the ACGME was in a better position to address the issue ...."39 Consequently, in 2003 the ACGME became the primary regulator of Resident duty hour reform in American hospitals. ${ }^{40}$

33. See generally Hren, supra note 1, at 459 ("Optimistic about future reform, proponents more recently shifted their focus on soliciting various regulatory agencies capable of enacting and enforcing resident work hour limitations.").

34. Id. See, e.g., PetrTION to OSHA, supra note 6.

35. Hren, supra note 1, at $\mathbf{4 6 0}$ (noting that after OSHA chose to adopt the guidelines promulgated by ACGME "the AMA, stating that resident work conditions are best addressed 'without regulation by agencies of the government,' announced that it too would rely on the guidelines set by the ACGME.").

36. Id. at 459 (" $[\mathrm{F}]$ or the first time in history, the American Medical Association (AMA) adopted new policy guidelines detailing specific definitions, hours, and working conditions for medical residents.").

37. Id.

38. Id. at 460. See, e.g., Letter from John L. Henshaw, Assistant Sec'y for Occupational Safety \& Health, U.S. Dep't of Labor, to Sydney M. Wolfe, Dir., Health Res. Group (Oct. 4, 2002), available at $\mathrm{http}: / / \mathrm{www} . c i t i z e n . o r g / d o c u m e n t s / A C F C 2 B . p d f$ [hereinafter Letter].

39. Hren, supra note 1, at 467 (internal citations omitted).

40. Id. at 460 ("In February 2003, the ACGME's final standards were approved and became effective for all accredited United States residency programs on July 1, 2003.”) 
2. The ACGME's Comprehensive Approach to Oversight: See No Evil, Hear No Evil, and Speak No Evil

The ACGME was relatively slow in adopting a comprehensive approach to limiting Resident duty hours. Indeed, by the time the ACGME adopted its duty hour standards "[a] number of other nations, including the United Kingdom, most other European nations, Canada and Australia [had already] limited hours for physicians in training by government regulation ....,41 The ACGME's slow response notwithstanding, however, its adoption of regulatory standards did constitute a grudging acknowledgment of the considerable body of scientific evidence demonstrating conclusively that "long hours and sleep loss have a negative effect on resident performance, learning and well-being." ${ }^{, 42}$ Even so, the ACGME's regulatory response, a response that imposed duty hour standards rather than restrictions, hardly constituted a polar shift in its approach to the Resident duty hour controversy. Moreover, the scheme employed by the ACGME to ensure hospital compliance with the standards has proven problematic.

As a private regulatory agency responsible for the accreditation and oversight of more than 7,800 medical programs the "ACGME relies on twenty-six specialty specific Residency Review Committees (RRCs) to develop its accreditation standards and to review resident programs for compliance with ACGME standards." residents provide high quality medical care by monitoring the educational quality of residency programs and the work environment to which Residents are exposed. ${ }^{44}$

In its current form, the comprehensive approach to regulating Resident duty hours adopted by the ACGME seeks to place suitable limits on those duty hours, increase institutional oversight of residency programs, and promote educational practices that enhance patient care. ${ }^{45}$ In general, the regulations limit Resident duty hours to eighty per week. ${ }^{46}$ More specifically, in any eighty-hour

41. ACCREDITATION COUNCIL FOR GRADUATE MED. EDUC., THE ACGME'S APPROACH TO Limit Resident Duty Hours: The Common STANDARDS and ACTivities to Promote ADHERENCE 1, available at http://www.acgme.org/acWebsite/dutyHours/dh_dhSummary.pdf [hereinafter COMMON STANDARDS].

42. Id.

43. Lin \& Liang, supra note 14, at 208-09 ("RRC members are appointed by the American Medical Association (AMA), the member board of the American Board of Medical Specialties, and in many specialties the academic specialty organization.").

44. See Interfaith Med. Ctr. v. Sabiston, 527 N.Y.S.2d 48, 49 (N.Y. App. Div. 1988), vacated in part, 143 A.D.2d 173 (N.Y. App. Div. 1988). See also Lin \& Liang, supra note 14, at 209 ("On average, hospitals have site visits every four years, and if programs meet the ACGME criteria, they may be accredited for up to five years.").

45. COMMON STANDARDS, supra note 41 , at 1.

46. ACCREDITATION COUNCIL FOR GRADUATE MED. EdUC., ACGME Highlights ITS STANDARDS ON RESIDENT DUTY HouRS (2001), http://www.acgme.org/acWebsite/resInfo/ ri_OSHAresp.asp (last visited Apr. 9, 2008). 
work week, no more than twenty-four continuous duty hours may occur back to back, rest periods between duty shifts must be provided, an in-house call must be scheduled no more frequently than every third night, and one day in seven must be free of program responsibilities. ${ }^{47}$ These regulations are not, however, inviolable. Indeed, as stated above, they are not restrictions. Rather, they are flexible standards permitting Residents to exceed the suggested number of weekly duty hours if doing so will enhance their education. ${ }^{48}$ Logically, the unique nature of a Resident's educational experience and the unpredictable nature of medicine require the inclusion of this exception. Its inclusion, however, provides hospitals and supervising physicians with the requisite means, opportunity, and rationale to circumvent the spirit of the ACGME standards at will.

In recognition of the obvious loophole in the ACGME regulations, the ACGME seeks to promote enhanced adherence to its Resident duty hour standards by requiring RRCs to routinely collect and monitor Resident duty hour scheduling information from accredited hospitals. ${ }^{49}$ Specifically, RRC's are required, through inspections and interviews with residents, to measure compliance with resident duty hour standards. ${ }^{50}$ Moreover, the ACGME has also established a formal process for investigating allegations of program noncompliance filed by Residents and others with knowledge of purported Resident duty hour scheduling violations. ${ }^{51}$

To ensure the efficacy of its oversight regime, RRCs are themselves subject to various oversight mechanisms. ${ }^{52}$ Thus, in theory, RRCs possess the credibility and power necessary to monitor residency programs, and may issue citations to any programs that fail to substantially comply with its stated standards. ${ }^{53}$ Moreover, if an accredited residency program fails to comply with the Resident duty hour standards after receiving such a citation, the RRCs are permitted to terminate the program's ACGME accreditation. ${ }^{54}$ In practice, however, both the regulatory powers of the RRCs and the draconian enforcement mechanisms at their disposal appear to amount to little more than smoke and mirrors. Indeed, despite the fact that Residents continue to report working un-

47. Id.

48. Id. ("[T] weekly limit.").

49. Id.

50. Lin \& Liang, supra note 14, at 235 ("ACGME measures compliance with these standards through on site [sic] inspections, including interviews with residents.") (citing ACCREDITATION COUNCIL FOR GRADUATE MED. EDUC., THE ACCREDITATION PROCESS AND THE ROLE OF THE ACGME SITE VISITOR (2007), http://www.acgme.org/acWebsite/fieldStaff/ fs_siteRole.asp (last visited Apr. 9, 2008)).

51. COMMON STANDARDS, supra note 41, at 1-2.

52. Id.

53. Lin \& Liang, supra note 14, at 235 ("ACGME also issues citations and monitors delinquent programs for 'substantial compliance' with its guidelines."

54. Ann Pomeroy, Medical School Council Urges Limits on Residents' Hours-HR NewsAccreditation Council for Graduate Medical Education, HR MAGAZINE, Apr. 2003, at 34 ("Residency programs that fail to comply with the standards can be placed on probation or have their accreditation withdrawn."). 
reasonably long hours in violation of ACGME standards, no institution has ever been relieved even temporarily of its ACGME accreditation. ${ }^{55}$ Thus, given that RRCs have not used the tools at their disposal to eliminate Resident duty hour abuses, the strength of the ACGME's standards themselves must be called into question.

\section{ACGME Duty Hour Standard Enforcement: Why It Doesn't Work}

There is ample evidence to suggest that the ACGME's oversight and enforcement of Resident duty hour regulations is largely ineffective, notwithstanding the "thoroughness" of these standards. 56 There are two reasons that the ACGME's duty hour standards are not effectively enforced: First, the ACGME has been substantially ineffective in enforcing the provisions of the regulations. Second, the regulations do not provide Residents with sufficient whistleblower protection to inspire widespread reporting of the duty hour violations to which they are routinely subjected.

\section{A Conglomerate of Agencies: Too Many Doctors Jumping on the Bed}

With regard to the issue of enforcement, advocates of Resident duty hour reform unilaterally assert that medical practitioners consider the ACGME duty hour standards weak and subject to voluntary compliance. ${ }^{57}$ This widely held belief is supported by the perception that the standards are unevenly enforced across medical specialties, an enforcement issue rooted in the very organizational structure of the ACGME. ${ }^{58}$ In its current form the ACGME's oversight power is effectively diffused among the "American Board of Specialties, the American Medical Association, the American Hospital Association, the Association of American Medical Colleges, and the Council of Medical Specialty Societies." 59 Consequently, even if the constituents of the ACGME were motivated to curtail Resident duty hour abuses, they would find it difficult, if not impossible, to act with the requisite unanimity of purpose to effectively regulate their own policies. ${ }^{60}$

55. Wilkey, supra note 12 , at 342-43 ("[P] ast experience demonstrates that the ACGME rarely finds violations, and if it does, the likelihood that a medical resident program will lose accreditation is close to nil.").

56. Id. at 342 .

57. $I d$. ("[T] $]$ he very culture of the medical profession promulgates a perception of the [ACGME] standards as superficial, amendable, and rarely enforceable.").

58. Id.

59. Id. at 342 .

60. Id. ("[T] he oversight power of the ACGME is essentially diffused among the participating organizations. In fact, as one council member expressed, 'the ACGME needs to act in a more independent manner ... the control of the parents inhibits the ACGME from acting in areas [it] needs to Act [sic]."' (quoting Frank, supra note 11, at 322)). 


\section{ACGME Accreditation: A Carrot and a Stick}

Organizational diversity is not, however, the only weakness in the ACGME's approach to enforcing Resident duty hour standards. Indeed, the necessity of maintaining ACGME program accreditation also undermines the effectiveness of the ACGME's primary oversight tool: Resident selfreporting. ${ }^{61}$ Resident self-reporting presupposes that Residents will actively report duty hour violations, and it is a key tool in the regulatory arsenal of the ACGME. Resident self-reporting has, however, proven to be an unreliable source of information, because Residents are reluctant to provide the ACGME with notice of duty hour violations. ${ }^{62}$ The reluctance of Residents to report a duty hour violation is rooted in the fact that medical residency programs require ACGME certification in order to receive the Medicare based GME funding on which they depend. ${ }^{63}$ Therefore, the loss of ACGME accreditation would have the effect of virtually shutting down a hospital's residency program.

Moreover, in order to be eligible for medical board certification, Residents must successfully complete an ACGME accredited program. ${ }^{64}$ Consequently, if a Resident report had the effect of shutting down a residency program, the careers of every Resident in the program would be put in jeopardy. Clearly, GME program funding and board certification are directly related to and flow from ACGME accreditation. ${ }^{65}$ Not surprisingly, both Residents and medical staff members usually refrain from reporting regulatory violations. Indeed, even though Residents "are fiduciaries to their patients" countable to their superiors for their future careers and would rather endure a few years of grueling working conditions than do anything which might compromise their careers." 67

Unfortunately, therefore, the possibility that Resident self reporting might force a hospital to forfeit ACGME accreditation and GME funding has done little to motivate change with regard to the resident duty hour issue. Indeed, hospitals do not fear the loss of ACGME accreditation since they know that

61. Wilkey, supra note 12, at 342 ("[D]etermining violations based on self-reporting methods such as surveys or questionnaires is problematic because medical staff and residents are reluctant to report the hospitals where they work for fear that their programs would lose accreditation.").

62. Id.

63. Lin \& Liang, supra note 14 , at 235.

64. Id. at 208-09 ("More than ninety percent of U.S. medical school graduates participate in postgraduate residency training and seek certification. Board certification significantly influences hospital privileges, peer and patient recognition, economic compensation, and the standard of care." (citing THE ROLE, supra note 14.)).

65. Lin \& Liang, supra note 14 , at 235 ("Programs that lose accreditation are virtually shut down because programs must be ACGME-accredited in order to receive Medicare GME funding that supports new residents.").

66. Sarah L. Geiger, The Ailing Labor Rights of Medical Residents: Curable Ill or a Lost Cause?, 8 U. PA. J. LAB. \& EMP. L. 523, 540 (2006).

67. Geiger, supra note 66 , at 539 . 
Residents have little motivation to self-report duty hour violations; thus, hospitals enforce Resident duty hour standards at will, if at all. One might argue that hospitals in violation of the ACGME standards should forfeit their accredited status simply because they continue to place Residents and patients at risk. An obvious solution to the problem created by the reluctance of Residents and other well-intentioned medical professionals to report duty hour violations would be to permit Residents and others to file anonymous complaints regarding the violation of duty hour standards. The ACGME, however, pointedly refuses either to consider anonymously filed complaints ${ }^{68}$ or to provide whistleblower protections to those who file formal complaints. ${ }^{69}$ Consequently, in spite of ACGME Resident duty hour standards, many chronically sleep-deprived Residents continue to practice medicine in America's hospitals.

\section{The Greatest Weakness: A Lack of Whistleblower Protection}

In a very real sense, Residents rely on the benevolence and professional acumen of their medical peers for career advancement. ${ }^{70}$ Therefore, few Residents are willing to complain to the ACGME, or to anyone else, when they are required to work irrationally long hours because they fear retaliatory discharge. ${ }^{71}$ Furthermore, those Residents that do raise allegations of regulatory violation, in the hope of improving working conditions and enhancing the quality of care, risk having their programs terminated; thereby, inspiring the ire of their contemporaries and discrediting the academic reputations of the very institutions and superiors to which they are looking for career advancement. ${ }^{72}$ Consequently, "the question of ... whether or not whistleblower protections would result in more favorable working conditions for medical residents ...." is central to the issue of duty hour enforcement. ${ }^{73}$ Indeed, many observers believe that federal enforcement of Resident duty hour limitations is necessary to ensure that hospitals with Graduate Medical Programs comply with ACGME regulations. $^{74}$

68. Lin \& Liang, supra note 14, at 235 ("Anonymous complaints are not considered by ACGME, the complainant must provide [a] name and mailing address." (citing ACCREDITATION COUNCIL FOR GRADUATE MED. EDUC., ACGME PROCEDURES ADDRESSING COMPLAINTS AGAINST RESIDENCY PROGRAMS (2007), http://www.acgme.org/acWebsite/resInfo/ri_complaint.asp (last visited Apr. 9, 2008)).

69. Pomeroy, supra note 54, at 34 ("Residents are beholden to their supervisors, and whistleblower protection is inadequate.").

70. Geiger, supra note 66, at 539.

71. Wilkey, supra note 12 , at 342 ("[D]etermining violations based on self-reporting methods such as surveys or questionnaires is problematic because medical staff and residents are reluctant to report the hospitals where they work for fear that their programs would lose accreditation.").

72. Pomeroy, supra note 54 , at 34.

73. Wilkey, supra note 12 , at 346.

74. Pomeroy, supra note 54, at 34 ("[The Committee of Interns and Residents] believes that federal enforcement of work hour restrictions is necessary ...."). 
The intimate relationship between retaliatory discharge and whistleblower protection is well documented in the United States. ${ }^{75}$ Moreover, whistleblower protections have been used to enforce labor statutes, laws, and legislative mandates, ${ }^{76}$ and have also been routinely applied to individuals working in the healthcare industry. ${ }^{77}$ Thus, the fact that Residents are constrained by custom and socioeconomic reality from raising allegations of hospital non-compliance with the ACGME duty hour regulations adopted by OSHA raises issues uniquely suited to the application of whistleblower protections. ${ }^{78}$

Proponents of Resident duty hour limitations assert that whistleblower protections should be extended to Residents because they are uniquely situated to determine when violations of ACGME duty hour limitations are occurring. ${ }^{79}$ conversely, most "hospitals vehemently oppose extending whistleblower protection to medical residents." ${ }^{80}$ Hospital administrators and the AMA have raised managerial concerns, arguing that providing Residents such protections might increase pending litigation against their hospitals; thereby, reducing the hospital's ability to deliver effective health care, ${ }^{81}$ and impeding the effective management of their organizations' internal affairs. ${ }^{82}$ Medical educators, on the other hand, are less concerned with the potential loss of managerial efficiency and more concerned about the potential loss of academic freedom. ${ }^{83}$ They argue that extending whistleblower protections should remain a discretionary issue so that residency programs are not faced with the necessity of reducing educational efficiency so as to satisfy an arbitrary "maximum-hour regime.",84

75. Wilkey, supra note 12, at 346 ("“W] ithin the United States, the relationship between whistleblower protection and retaliatory discharge is well documented.").

76. Id. ("The use of whistleblower protection as a means to enforce particular labor statutes, laws, or legislative mandates is not new.").

77. Id. ("The application of whistleblower protection to health professionals is not a new concept either.").

78. Id. "'Integral to the conceptual framework embodied in whistleblower protection is the probability that employers will retaliate against employees in the form of harassment, demotion, or termination.").

79. See generally Virginia U. Collier et al., Stress in Medical Residency: Status Quo after a Decade of Reform, 136 ANNALS INTERNAL MED. 384, 384 (2002) (providing factual accounts of residents observing and experiencing violations of maximum-hour guidelines).

80. Wilkey, supra note 12, at 352 (citing AM. MED. STUDENT Ass'N, RESIDENT WORK HOUR ISSUE DEBATE SHEET 1 (2007), http://www.amsa.org/rwh/952debate.cfm (suggesting that hospitals do not think that the extension of whistleblower protection will be an adequate incentive for self-reporting among Residents) (last visited Apr. 9, 2008)).

81. Id. ("[T]here is concern that both physicians and patients may be deterred from disclosing specific information in reports, records, and charts in the fear that it may be subpoenaed at a future date." (citing Statement for the Record Submitted by the American Academy of Family Physicians, House Comm., Ways and Means, Subcommittee on Health (Sept. 10, 2002))).

82. Id. ("[O]rganizations such as the AMA view the extension of whistleblower protection as an impediment to the management and internal affairs of hospitals.").

83. See id.

84. Id. ("Another concern with extending whistleblower protection is the issue of discretion: medical residency programs have educational requirements that may necessitate time commitments that cannot be met under a maximum-hour regime."). 
Other critics simply contend that extending whistleblower protections to Residents will exacerbate the systemic problems posed by ever-rising healthcare costs, growing malpractice insurance premiums, and shrinking education budgets. ${ }^{85}$ Thus, the Resident duty hour regulations promulgated by the ACGME and adopted by OSHA are neither widely accepted, nor adequately enforced by most influential participants in the American medical community.

\section{State and Federal Legislative Attempts to Curtail Duty Hour Violations}

In stark contrast to the positions taken by hospital administrators, medical academics, and professional organizations like the AMA, patients rights groups, Residents, and the AMSA all support both the equitable enforcement of the ACGME's duty hour regulations, and legislative efforts to enhance the effectiveness of those regulations by providing Residents with whistleblower protections. Moreover, the apparent unwillingness and inability of medical professionals to establish and enforce reasonable duty hour standards has prompted many government actors to promulgate legislation aimed at ensuring hospital compliance with duty hour standards.

The Bell Regulations constituted an initial attempt by a state government to reform the healthcare polices and duty hour standards of American hospitals. ${ }^{86}$ These regulations were established in 1998 by way of an amendment to the New York State health code, after a report revealed that Residents were working dangerously long hours. ${ }^{87}$ The Bell Regulations were similar in scope to the 2003 ACGME standards in that they attempted to impose explicit limits on the number of hours Residents were permitted to work. ${ }^{88}$ Unfortunately, they also met with similar difficulties. ${ }^{89}$ The Bell Regulations lack of whistleblower protections notwithstanding, they also failed to consider that members of the medical community "are most supportive of steep hierarchies in which junior staff do not question senior staff." 90 As such, healthcare providers objected "voraciously" to being saddled with externally imposed work hour

85. Id. (" $[\mathrm{I}] \mathrm{n}$ an era of rising healthcare costs, shrinking funds at teaching facilities and increasing legal malpractice premiums, critics contend that whistleblower protection would aggravate an ailing health care system.").

86. Whetsell, supra note 7, at 63 ("[T] he Bell Regulations ... purpose was to regulate residents' work hours and supervision of their patient care.").

87. See generally Lin \& Liang, supra note 14, at 240 (discussing how the investigation into the death of a patient at the hands of an exhausted Resident prompted New York to rethink the Resident duty hour controversy).

88. Id. ("The Bell Regulations now limit resident hours to eighty hours per week, averaged over a four week period, and no more than twenty-four consecutive hours.").

89. Id. ("Noncompliance was ... noted by ... the New York State Health Department, which cited fifty-four out of the state's eighty-two teaching hospitals for resident work hour violations during the period from November 1, 2001, through June 21, 2002.").

90. Whetsell, supra note 7, at 63-64. 
restrictions that undermined the near absolute authority traditionally granted them by the age-old master-apprentice model of medical instruction. ${ }^{91}$

In 2000, in the wake of OSHA's adoption of the ACGME's Resident duty hour standards and enforcement regime, there was strong bipartisan support for federal legislation intended to promote the safety and well being of patients and Residents alike. ${ }^{92}$ Specifically, two bills introduced in the United States Senate (referred to collectively herein as the "2000 Acts") sought to impose the "voluntary (but not mandatory) reporting of medical errors" and provided various protections for medical professionals and their patients. ${ }^{93}$ Similar in form to the Bell Regulations, the 2000 Acts sought to impose explicit Resident work hour limitations. ${ }^{94}$ Unfortunately, despite strong support from major players in the health care industry, neither proposition ever received a floor vote. ${ }^{95}$

More recently, the Patient and Physician Safety and Protection Acts of 2001 ("House Bill 3236"), ${ }^{96}$ the Patient and Physician Safety and Protection Act of 2003 ("House Bill 1228"), ,7 $^{7}$ and the Patient and Physician Safety and Protection Act of 2005 ("House Bill 1297") 98 were introduced in the United States House of Representatives. Like the Bell Amendments and the 2000 Act, each of these bills attempted to impose strict limitations on the number of hours that a Resident could permissibly be required to remain on duty. ${ }^{99}$ Unlike the Bell Amendments, however, these bills included provisions intended to function as enforcement mechanisms. ${ }^{100}$ For example, under House Bill 3236, Res-

91. Id. at 64

There is great reluctance to abide by government standards for two additional reasons. First, hospitals traditionally have set their own standards, or theoretically follow the guidelines set by the accrediting organization and are generally suspicious of federal or state interference. The concern here is that regulations may be crafted by legislators who lack intimate knowledge of the heath care system and fail to understand the heterogeneity within America's health care system. Second, such regulations put in place yet another blame system, which violates the very idea of the patient safety movement. Aside from the possible citations and monetary penalties for failure to comply, an overwhelming fear of malpractice liability makes hospitals very defensive.

Id. (citation omitted).

92. Id. at 57 ("The past few years have seen some attempts at patient safety legislation.").

93. Id. at 57-58 (citing Linda O. Prager, Safety Bills Take Voluntary Tack on Reporting Errors, AM. MED. NEws, July 2000, at 6).

94. David Abel, Bill Eyes Guidelines on Work Hours for Medical Residents, BostoN GLOBE, Nov. 10, 2001, at B1 (noting that the bills effectively limited total Resident duty hours to eighty per week, Resident shift lengths to twenty-four consecutive hours, and guaranteed that Residents would receive at least one day off per week and one full weekend off per month.).

95. Adams, supra note 18, at 1 (noting that despite strong support "[n]either proposal reached a vote.").

96. See H.R. 3236, 107th Cong. (2001).

97. See H.R. 1228, 108th Cong. (2003).

98. See H.R. 1297, 109th Cong. (2005).

99. Abel, supra note 94, at B1.

100. C.f., Whetsell, supra note 7, at 58 (reviewing the regulatory provisions of H.R. 3236). 
idents would be required to complete anonymous surveys to ensure hospital compliance, ${ }^{101}$ a committee would be required to conduct annual on site inspections to assess the validity of the survey results, ${ }^{102}$ and a substantial pool of federal funds would be made available to hospitals that incurred reasonable additional costs in achieving substantial compliance with the terms of House Bill 3236. ${ }^{103}$

More importantly, however, House Bill 3236 and its progeny also permitted Residents to report duty hour violations directly to the Secretary of Health and Human Services, ${ }^{104}$ provided reporting Residents with whistleblower protections, ${ }^{105}$ and proposed stiff fines of up to $\$ 100,000.00$ for hospitals found guilty of violating the statute. ${ }^{106}$ Ultimately, in each of its incarnations, the $\mathrm{Pa}$ tient and Physician Safety and Protection Act proposed amendments intended to reduce Resident duty hours and enhance the supervision of Residents; thereby, ensuring the safety of both the Residents and their patients. ${ }^{107}$ Unfortunately, like the 2000 Acts all of these subsequent acts also stalled in committee. ${ }^{108}$

Despite the best efforts of the AMSA, patient advocacy groups, and legislatures on both the state and national levels, hospital administrators, medical educators, and professional medical organizations have, to date, successfully rebuffed all attempts at Resident duty hour reform. Recent decisions in the Seventh and Ninth Circuits may, however, provide the tools necessary to breach the ivory tower of medical education, provide Residents with the whistleblower

101. H.R. 3236 at $\S 3(\mathrm{~b})(4)(A)$ (stating that an individual within the Department of Health and Human Services shall "provide for annual anonymous surveys of postgraduate trainees to determine compliance with such requirements [designated herein] and for disclosure of the results of such surveys to the public on a residency-program specific basis.").

102. Id. at $\S 3(\mathrm{~b})(4)(\mathrm{B})$ (stating that based on the contents of the annual anonymous surveys completed by residents in accordance with section 3(b)(4)(A) of the H.R. 3236, an individual within the Department of Health and Human Services shall in accordance with H.R. 3236 3(b)(4)(B) "conduct appropriate on-site investigations.").

103. Id. at $\S 4$

There are hereby appropriated to the Secretary of Health and Human Services such [funds] as may be required to provide for additional payments to hospitals for their reasonable additional, incremental costs incurred in order to comply with the requirements imposed by [this] Act (and the amendments made by this Act).

Id.

104. Id. at $\S 3(\mathrm{~b})(2)$ ("A post graduate trainee or physician resident may file a complaint with the Secretary of Health and Human Services ... . [s] uch a complaint may be filed anonymously. The Secretary may conduct an investigation and take such corrective action with respect to such a violation.").

105. Id. at $\S 3$ (c) ("A hospital . . shall not penalize, discriminate, or retaliate . . against an employee ... who in good faith . . . . reports a violation or suspected violation of such requirements to a public regulatory agency, a private accreditation body, or management personnel of the hospital.").

106. Id. at $\S 3(\mathrm{~b})(3)$ ("Any hospital that violates such requirement is subject to a civil money penalty not to exceed $\$ 100,000$ for each resident training program in any 6 -month period.").

107. Compare H.R. 3236 with H.R. 1228 and H.R. 1297.

108. Whetsell, supra note 7, at 58. 
protections proposed in the House Bill 3236 and its progeny, and promote hospital compliance with the ACGME's Resident duty hour standards.

\section{MAKING THE GRADE: CAN GRADUATE MEDICAL EDUCATION WITHSTAND THE ASSAULT OF ACTIONS BROUGHT PURSUANT TO FEDERAL THE FALSE CLAIMS ACT?}

\section{A. The Importance of Main \& Chapman}

The reluctance and apparent inability of the ACGME to ensure broad hospital compliance with its Resident duty hour standards notwithstanding, recent decisions in the federal courts have exposed non-compliant hospitals with federally funded GME programs to liability under the FCA. Specifically, the recent decisions in United States ex rel. Main v. Oakland City University and United States $v$. Chapman University have endorsed a legal theory that increases the liability exposure, under the FCA, of federally subsidized institutions of higher education. ${ }^{109}$

\section{B. The False Claims Act Generally}

\section{The Applicability of the False Claims Act}

The FCA, originally enacted in $1863,{ }^{110}$ grants private individuals standing to file suit in federal court in the name of the federal government. ${ }^{111}$ As amended in 1986, "the FCA imposes civil liability upon '[a]ny person' who, inter alia, 'knowingly presents, or causes to be presented, to an officer or employee of the United States Government . . . a false or fraudulent claim for payment or approval.""112 Thus, actionable claims filed pursuant to the FCA must first establish that the defendant is a person within the meaning of the

109. See generally United States v. Chapman Univ., No. SACV 04-1256JVSRCX, 2006 WL 1562231, at *2 (C.D. Cal. May 23, 2006); United States ex rel. Main v. Oakland City Univ., 426 F.3d 914, 916 (7th Cir. 2005).

110. Vt. Agency of Natural Res. v. United States ex rel. Stevens, 529 U.S. 765, 768 (2000) ("Originally enacted in 1863, the False Claims Act (FCA) is the most frequently used of a handful of extant laws creating a form of civil action known as qui tam.").

111. 31 U.S.C. $\$ 3730(b)(1)$ (2007)

A person may bring a civil action for . . . the person and for the United States Government. The action shall be brought in the name of the Government. The action may be dismissed only if the court and the Attorney General give written consent to the dismissal and their reasons for consenting.

Id.

112. Vt. Agency, 529 U.S. at 769 (citing 31 U.S.C. $\S 3729(a)(1)(2007)$ ). 
Act, ${ }^{113}$ and second, that the defendant acted knowingly to defraud the United States Government of federal funds. ${ }^{114}$

\section{Persons Amenable to Suit Under the False Claims Act}

The United States Supreme Court (the "Court") has held that the FCA applies to any "person" who makes a knowingly false claim on the United States Government for federal funds. ${ }^{115}$ Ironically, however, the FCA does not explicitly define the term "person." "116 Historically, there has been confusion regarding the general applicability of the FCA to state actors.

This dilemma was resolved in Vermont Agency of Natural Resources $v$. United States ex rel. Stevens, where the Court stated unequivocally that the term person as used in the FCA "does not include the sovereign." 117 Moreover, the Seventh Circuit extended the protections afforded to the sovereign in Vermont Agency to officials of a state or state agency acting in their professional capacities. $^{118}$

States and state agencies are not, however, entirely immune to prosecution under the FCA. If an action is brought pursuant to the Civil Investigative Demand ("CID") provisions of the FCA, which apply only to government actors, such as the Attorney General of the United States (the "Attorney General"), states are defined as persons. ${ }^{119}$ Thus, under the FCA, private individuals have the requisite standing to bring suit in federal court on behalf of the United States so long as the party subject to suit is not a state, state agency, or a state actor. ${ }^{120}$ If one of those entities is implicated, however, only a representative of

113. 31 U.S.C. $\$ 3729$ (a)(1) (indicating that the Act applies to "[a] ny person.").

114. United States ex rel. Nudelman v. Int'1 Rehab. Assocs., Inc., No. 00-1837, 2006 WL 925035, 13 (E.D. Pa. April 4, 2006) ("[N] ot all false statements made to the federal government are claims within the meaning of the False Claims Act; only actions which have the purpose and effect of causing the government to pay out money are clearly 'claims' within the purpose of the Act.").

115. 31 U.S.C. $\$ 3729$ (a)(1).

116. See generally 31 U.S.C. $\$ \S 3729-3733$ (2007).

117. Vt. Agency, 529 U.S. at 780; see also United States ex rel. Krahel v. Regents Univ. of Cal., No. C-96-1703 WHO, C-01-1893, 2001 WL 1548786, at *2-3 (N.D. Cal. Sept. 13, 2001), aff'd, 329 F.3d 1040 (9th Cir. 2003) (stating that States and State agencies are not persons subject to being sued in a Qui tam action under the FCA).

118. Pond v. Bd. of Trs., Ball State Univ., No. 1:03-CV-00755-LJM-VS, 2004 WL 2538645, at *11 (S.D. Ind. Sept. 9, 2004) ("A lawsuit against an official of the state, or of an agency of the state, in his 'official capacity' is a suit against the state entity itself." (quoting Kentucky v. Graham, 473 U.S. 159, 166 (1985))).

119. See 31 U.S.C.A § 3733(a)(1), (4) (West 2007); see also Vt. Agency, 529 U.S. at 78384 ("[T] he FCA ... enables the Attorney General to issue civil investigative demands to 'any person ... possessi[ng] information relevant to a false claims law investigation'. . . expressly defining 'person,' '[f] or purposes of this section,' to include States . . ..").

120. See Vt. Agency, 529 U.S. at 787 ("In sum, we believe that various features of the FCA, both as originally enacted and as amended, far from providing the requisite affirmative indications that the term 'person' included States for purposes of qui tam liability, indicate quite the contrary."). 
the federal government may file suit pursuant to the CID provisions of the FCA. ${ }^{121}$

The question of whether or not a state actor can be considered a person within the meaning of the FCA is particularly important when considering the application of the FCA to medical facilities with GME programs. Although it is clear that both private for-profit and public not-for-profit hospitals would constitute persons within the meaning of the FCA, prior to the Court's ruling in Vermont Agency, it was unclear whether state-run hospitals and hospitals affiliated with state institutions of higher learning would be amenable to suit under the FCA. Given the Court's ruling in Vermont Agency, as interpreted by the Seventh Circuit, however, such hospitals would clearly be amenable to suits filed under the CID provisions of the FCA.

The attentive reader may, at this point, be wondering how the FCA can so neatly sidestep the doctrine of sovereign immunity established by the Eleventh Amendment. In fact, the Court has held that no Eleventh Amendment issue arises when considering whether or not a state may be sued under the FCA. ${ }^{122}$ In pertinent part, the Eleventh Amendment states that " $[t]$ he Judicial power of the United States shall not be construed to extend to any suit in law or equity, commenced or prosecuted against one of the United States by [its] Citizens ... .123

In Vermont Agency, the Court considered once more the legal tension existing between the Eleventh Amendment and statutory law. ${ }^{124}$ With regard to actions against the state, the Court noted that the "statutory question [is] 'logically antecedent to the existence of' the Eleventh Amendment question," when questions regarding an Eleventh Amendment prescription against enforcing a statutory cause of action against a state must be balanced against a statute's own prescription prohibiting enforcement of such a cause of action. ${ }^{125}$ The Court concluded that by addressing the statutory question first, there was no "realistic possibility" of expanding the Court's power beyond judicial limitations imposed by the Constitution. ${ }^{126}$ Moreover, the Court determined that the "combination of logical priority and virtual coincidence of scope [made] it possible, and indeed appropriate, to decide the statutory issue first.",127

According to the Court, "longstanding interpretive presumption" suggested that states were not "persons" within the meaning of the FCA and that

121. See 31 U.S.C.A. $\$ \S 3730,3733$ (West 2007).

122. Cf., Vt. Agency, 529 U.S. at 779.

123. U.S. CoNST. amend. XI.

124. 529 U.S. at 779 ("We nonetheless have routinely addressed before the question whether the Eleventh Amendment forbids a particular statutory cause of action to be asserted against States ....").

125. Id. at 779 (quoting Amchem Prods., Inc. v. Windsor, 521 U.S. 591, 612 (1997)).

126. Id. at 779 (" $[\mathrm{T}]$ here is no realistic possibility that addressing the statutory question will expand the Court's power beyond the limits that the jurisdictional restriction has imposed.").

127. Id. at $779-80$. 
private individuals did not have standing to sue states under the FCA. ${ }^{128}$ Therefore, when balancing the prescriptions of the Eleventh Amendment against the implied statutory limitations of the FCA, the Court determined that the FCA itself precluded private individuals from instituting legal action against the state and saw no need to address the Eleventh Amendment issue at all. ${ }^{129}$

\section{Knowing Action Under the False Claims Act}

With regard to the FCA's knowledge requirement, the text of the FCA states that the knowledge requirement is satisfied when a defendant "has actual knowledge of ... information ... [but] acts in deliberate ignorance ... [or] reckless disregard of the truth or falsity of the information." 130 This prescription applies equally to claims filed by both private citizens and government actors bringing suit under the FCA's CID provisions. ${ }^{131}$ Moreover, because a claim brought pursuant to the FCA constitutes an averment of fraud, the claim will only be actionable if all allegations against the person who is the subject of the claim are pled with a particularity sufficient to satisfy the heightened pleading requirements of Federal Rule of Civil Procedure 9(b). ${ }^{132}$

\section{Bringing a Claim Pursuant to the False Claims Act: The Qui Tam Suit}

An action brought pursuant to the FCA can be commenced by either the United States Department of Justice, in the person of the Attorney General, or by a private individual known as a qui tam relator. ${ }^{133}$ If the qui tam relator commences the action on behalf of the United States it is referred to as a qui tam action. ${ }^{134}$ Regardless of who initiates the action, however, the "real party in interest in a qui tam action is the United States."

128. Id. at 780 .

129. Id.

130. 31 U.S.C. $\$ 3729(b)(1)-(3)(2007)$.

131. See 31 U.S.C. $\$ \S 3730(a), 3733(a)(1)$ (2007).

132. United States ex rel. Smith v. Boeing Co., No. 05-1073-WEB, 2006 WL 542851, at *3 (D. Kan. Feb. 27, 2006) ("'At a minimum, Rule 9(b) requires that a plaintiff set forth the who, what, when, where, and how of the alleged fraud." (quoting United States ex. rel. Schwartz v. Coastal Healthcare Group, No. 99-3105, 2000 WL 1595976, at *3 (10th Cir. Oct. 26, 2000))); see also United States ex rel. Donaldson v. Conservation Res. Alliance, No. 0310141-BC, 2006 WL 695674, at *3 (E.D. Mich. Mar. 14, 2006) ("[C]onclusory allegations that the defendants' conduct was fraudulent do not satisfy Rule 9(b).").

133. United States ex rel. Carey v. Brock, No. 3:04-CV-131, 2006 WL 1195887, at *2 n.2 (E.D. Tenn. May 2, 2006) ("This matter is pursued as a qui tam action. In a qui tam action, the plaintiff sues on behalf of and in the name of the government and invokes the standing of the government resulting from the fraud injury.").

134. BLACK's LAW DiCTIONARY 1251 (8th ed. 2004) (stating that qui tam is an abbreviation of the Latin phrase "qui tam pro domino rege quam pro se ipso in hac parte sequitur," meaning "who as well as for the king as for himself sues in this matter").

135. Carey, 2006 WL 1195887, at *2. 
The government may elect to intervene in a qui tam suit by a relator. ${ }^{136}$ If the government chooses to intervene and proceed with the qui tam action, it has "the primary responsibility for prosecuting the action and shall not be bound by any act of the private individual bringing the action." 137 Even after the government's intervention, however, the relator has the right to continue as a party to the action, subject to certain limitations. ${ }^{138}$ Thus, the qui tam plaintiff retains a private right of action under the FCA and is not merely a "statutorily designated agent of the United States." torney General, may also choose to proceed independently in an action brought pursuant to the CID provisions of the FCA. ${ }^{140}$

\section{Damage Liability Under the False Claims Act}

Defendants in actions brought pursuant to the FCA are liable for up to treble damages and a civil penalty of up to $\$ 10,000.00$ per claim. ${ }^{141}$ Generally, if the qui tam suit is successful the relator is eligible to receive a percentage of the funds recovered. ${ }^{142}$ The government may, however, choose to dismiss or settle the action at will. ${ }^{143}$

136. $C f$., Nudelman, 2006 WL 925035 , at $* 13$

An action under the False Claims Acts can be commenced in one of two ways. The United States Department of Justice (or the states' attorneys general under the state Acts) can file suit, or, alternatively, a private plaintiff can institute a qui tam action on behalf of the United States (or the individual State) to recover damages incurred due to fraudulent claims.

Id.

137. Id. (citing 31 U.S.C. \& $3730(\mathrm{c})(1)$ ).

138. 31 U.S.C. $\$ 3730$ (c)(1) ("If the Government proceeds with the action, it shall have the primary responsibility for prosecuting the action, and shall not be bound by an act of the person bringing the action. Such person shall have the right to continue as a party to the action, subject to ... limitation ....").

139. Vt. Agency, 529 U.S. at 772.

140. See generally 31 U.S.C. $\$ \S 3730,3732$ (a) (2007).

141. 31 U.S.C. $\$ 3729$ (a)(1)-(7)

Any person who ... knowingly makes, uses, or causes to be made or used, a false record or statement to conceal, avoid, or decrease an obligation to pay or transmit money or property to the Government, is liable to the United States Government for a civil penalty of not less than $\$ 5,000$ and not more than $\$ 10,000$, plus 3 times the amount of damages which the Government sustains because of the act of that person ....

Id.

142. See 31 U.S.C. $\$ 3730$ (d)

If the Government proceeds with an action brought by a person ... such person shall, subject to the second sentence of this paragraph, receive at least 15 percent but not more than 25 percent of the proceeds of the action or settlement of the claim, depending upon the extent to which the person substantially contributed to the prosecution of the action."). But see Carey, 2006 WL 1195887, at *2 (discussing qui tam relator's share in the damages recovered in an action commenced under the FCA and holding that "the re- 


\section{Whistleblower Protections Under the False Claims Act}

The FCA includes protections for whistleblowers that reflect the obvious federal interest in protecting informants who play an integral and necessary role in exposing fraud against the government. ${ }^{144}$ For example, the FCA protects employees from retaliatory action, including harassment, suspension, and discharge, resulting from their participation in or initiation of a qui tam action brought pursuant to the FCA. ${ }^{145}$

\section{a. Protection and relief for whistleblowers: Employers beware}

Once a qui tam action is filed, whistleblowers are eligible for protection and relief, including reinstatement and an award of damages. ${ }^{146}$ Moreover, as long as the government and employer are on notice that an employee is engaging in a protected activity, the fact that the Attorney General settles a claim does not limit the protections offered by the Act. ${ }^{147}$ Such a settlement will also not bar a whistleblower's independent suit for retaliatory discharge. ${ }^{148}$ Furthermore, persons discharged from employment for participating in a protected activity may bring suit to recover damages. Whistleblower retaliation claims brought pursuant to the FCA must, however, be commenced "within the time allowed by the most closely analogous state law limitations period.",149

Id.

lator has no personal stake in the damages sought by the government.

143. 31 U.S.C. $\$ 3730(\mathrm{c})(2)(\mathrm{A})$-(B)

The Government may dismiss the action notwithstanding the objections of the person initiating the action.... The Government may [also] settle the action with the defendant notwithstanding the objections of the person initiating the action if the court determines, after a hearing, that the proposed settlement is fair, adequate, and reasonable under all the circumstances.

Id.

144. See Campbell v. Aerospace Corp., 123 F.3d 1308, 1315 (9th Cir. 1997).

145. 31 U.S.C. $\$ 3730(\mathrm{~h})$

Any employee who is discharged, demoted, suspended, threatened, harassed, or in any other manner discriminated against in the terms and conditions of employment by his or her employer because of lawful acts done by the employee on behalf of the employee or others in furtherance of an action under this section, including investigation for, initiation of, testimony for, or assistance in an action filed or to be filed under this section, shall be entitled to all relief necessary to make the employee whole ... [including] reinstatement ...2 times the amount of back pay, interest on the back pay, and compensation for any special damages sustained as a result of the discrimination, including litigation costs and reasonable attorneys' fees.

Id.

146. See id.

147. Id.

148. See generally Neal v. Honeywell, Inc., 33 F.3d 860 (7th Cir. 1994).

149. United States ex rel. Smith v. Yale Univ., No. 3:02CV1205, 2006 WL 1168446, at *3

n.3 (D. Conn. April 28, 2006). 


\section{b. Federal jurisdiction: Retaliatory discharge and whistleblower actions}

In order to establish federal court jurisdiction over the retaliatory discharge claim, a plaintiff must prove that he placed his employer on notice that he was participating in an activity protected by the FCA. ${ }^{150}$ The plaintiff may establish notice if: (1) actions were taken in furtherance of a qui tam suit; (2) the employer knew of the actions; and (3) discharge occurred because of the actions. $^{151}$

With regard to the extension of federal jurisdiction to wrongful termination actions brought in state courts, both the Sixth and Ninth Circuits have rejected the notion that the FCA "justified the exercise of federal jurisdiction over a state wrongful termination action." "152 The courts held that:

[T] he FCA's procedures augured against finding a substantial federal question in a state action relying on the FCA . . . because a state-law tort claim so grounded would circumvent the procedures and limitations of the FCA, and a contrary finding would open a "[sic] back door" into federal court for what essentially was a state tort action. ${ }^{153}$

Thus, the whistleblower provisions of the FCA apply only to qui tam actions commenced in the federal courts.

\section{c. Whistleblower actions: Essential elements and limitations}

The prior commencement of a qui tam action is the essential element in establishing a right of action in a whistleblower claim brought pursuant to the FCA. Qui tam actions may not, however, be commenced against a state or a state agency by a private individual. Therefore, because qui tam actions cannot generally be commenced against the state, and without a qui tam action no right of action in a whistleblower claim exists against the state, an arm of the state cannot be sued in a whistleblower action.

The Sixth and Ninth Circuits have held that the FCA does not extend federal jurisdiction over wrongful termination actions initiated in state courts. Thus, although the Court did not address the issue of retaliatory discharge in

150. See generally Robertson v. Bell Helicopter Textron, Inc., 32 F.3d 948 (5th Cir. 1994) (holding that failure to establish a nexus between the filing of a qui tam action and discharge may result in a determination by the court that the employee was not engaged in a protected activity and therefore not amenable to the protections of the FCA).

151. Id.

152. Eastman v. Marine Mech. Corp., 438 F.3d 544, 552 (6th Cir. 2006) (construing Campbell v. Aerospace Corp., 123 F.3d 1308, 1315 (9th Cir. 1997)).

153. Eastman, 438 F.3d at 553 (quoting Campbell, 123 F.3d at 1315). 
Vermont Agency, it can be presumed that states and state agencies are not amenable to suit by private individuals bringing whistleblower claims pursuant to the FCA. States and state agencies may, however, be amenable to such suits if third party federal actors commence them. In such situations, whistleblower protections may well apply to adversely-affected private parties.

\section{Government Funding of Graduate Medical Education: The Essential Link}

The FCA is "broadly phrased" to reach "'any person' who violates its provisions" by knowingly defrauding the federal treasury. ${ }^{154}$ As such, hospitals that rely on federal funds to pay their Residents, medical educators, and support staffs, would seem to be subject to liability under the FCA. Moreover, Residents working in GME programs would seem to have the standing required to bring qui tam suits, subject to the whistleblower protections, if those programs forced them to work dangerously long hours. Indeed, even in cases where such violations are carried out by state actors in state hospitals, the Attorney General would likely have standing to file suit pursuant to the FCA's CID provisions.

Assuming arguendo that proponents of Resident duty hour reform are correct in their assertion that knowing violations of the ACGME's duty hour standards occur routinely in America's teaching hospitals, can the FCA be applied to the problem? Prior to OSHA's adoption of the ACGME's Resident duty hour standards and enforcement regime, the answer to this question would probably have been: No. Indeed, despite the fact that the federal government has long served as the largest single source of funding for GME programs in public, private, and state run hospitals, prior to OSHA's adoption of the ACGME standards, compliance with those standards did not form a link in the chain of causation leading to the release of funds from the federal treasury. ${ }^{155}$

Moreover, even after the federal government adopted the ACGME's standards, the ACGME monitored compliance with those standards. As a result, knowingly non-compliant hospitals seeking the ACGME accreditation necessary to serve as centers of GME could apply for federal funding without making a knowingly false claim regarding compliance to the federal government. Indeed, if a false claim regarding compliance with ACGME standards was made at all, it was made to the ACGME, a private accreditation group unrelated to the federal government and free from federal oversight. In such cases, the knowing falsehood formed a link in the chain of causation leading to the release of fed-

154. United States ex rel. Garber v. City of New York, 8 F. Supp. 2d 343, 352 (2nd Cir. 1998) (construing United States v. McNinch, 356 U.S. 595, 599 (1958)).

155. Press Release, Ctrs. for Medicare \& Medicade Servs., Office of Pub. Affairs, FY 2007 Hosp. IPPS Proposed Rule - Graduate Med. Educ. (Apr. 12, 2006) (on file with author), http://www.cms.hhs.gov/apps/media/press/release.asp?Counter=1835 ("Financing of graduate medical education (GME) - the period of training following graduation from medical school -is provided predominantly through inpatient revenues (both hospital payments and faculty physician fees) and a mix of Federal and State government funds."). 
eral funds, but it was too attenuated to trigger liability under the FCA. Thus, despite OSHA's adoption of the ACGME standards, hospitals could, without fear of prosecution under the FCA, knowingly violate those standards. After the Main and Chapman decisions, however, hospitals no longer enjoy such freedom of action.

\section{The False Claims Act: Expanding Applicability}

Recent federal court decisions in the Seventh and Ninth Circuits have endorsed a legal theory that extends the scope of FCA liability to false certifications of compliance made in the first phase of a multi-phase certification process. ${ }^{156}$ Under this theory, false certifications of compliance no longer need to be made directly to the federal government in order to incur liability under the FCA. ${ }^{157}$ Rather, to establish an actionable claim a plaintiff need only establish that the defendant knowingly made a false or fraudulent certification of compliance, ${ }^{158}$ and that the false certification of compliance formed a link in a chain of causation ultimately leading to a demand on the federal treasury. ${ }^{159}$

\section{One lie begets another: The chain of causation grows longer}

In Main, a private individual brought a qui tam action under the FCA against his former employer alleging that his employer, a private university, made fraudulent assertions regarding its eligibility to receive subsidies from the federal treasury through the United States Department of Education. ${ }^{160}$ The Department of Justice did not choose to intervene in the action. ${ }^{161}$ Specifically,

156. See generally Main, 426 F.3d at 914; Chapman, 2006 WL 1562231, at *1.

157. Id.

158. United States ex rel. Hopper v. Anton, 91 F.3d 1261, 1266 (9th Cir. 1996) ("In furthering this goal, the Act attaches liability, not to underlying fraudulent activity, but to the 'claim for payment.' What constitutes the FCA offense is the knowing presentation of a claim that is either fraudulent or simply false." (quoting United States ex rel. Hagood v. Sonoma County Water Agency, 929 F.2d 1416, 1421 (9th Cir. 1991))).

159. Main, 426 F.3d at 916 ("The [FCA] requires a causal rather than a temporal connection between fraud and payment.").

160. Id.

Oakland City University assured the Department of Education on its phaseone application that it complies with the rule against contingent fees .... [T] he relator in this qui tam action under the False Claims Act... contends that the University's representation was fraudulent. According to the complaint, Main himself received contingent fees as a recruiter and later as the University's Director of Admissions. Initially Main thought the compensation system proper, but when he learned of the federal statute and rule he filed this suit.

Id.

161. Id. at 917 ("The Department of Justice, though it elected not to take over the litigation ... has filed a brief as amicus curiae in this court contending that the allegations of the complaint, if true, demonstrate a right to recover under the False Claims Act."). 
the qui tam relator contended that the university asserted willful falsehoods regarding its compliance with federal regulations during the first phase of the application process, and as a result, the university was amenable to suit under the FCA. ${ }^{162}$ The district court dismissed the action on the grounds that "willful falsehoods in phase-one applications [did] not violate the Act, because the phase-one application request[ed] a declaration of eligibility rather than an immediate payment from the treasury." ${ }^{163}$ The district court also noted that the willful falsehood was not repeated in the phase-two application, the application that directly preceded the demand on the treasury of the United States. ${ }^{164}$

On appeal the Seventh Circuit reversed, arguing that but for the willful falsehood asserted in the phase-one application the phase-two application for payment could not have been made. ${ }^{165}$ Specifically, the appellate court reasoned that the fraudulent statement made by the university in the phase-one application "caused" the phase-two applications to be submitted. ${ }^{166}$ The fraudulent statement in the phase-one application was, therefore, an integral element in the "causal chain leading to payment" by the federal government. ${ }^{167}$ Thus, Main expanded the FCA to encompass fraudulent claims made by a private university, in the first phase of a two-phase application process for federal subsidies, even though the first phase did not include an immediate demand for payment from the United States Treasury.

\section{A chain attenuated does not break: Reaping what you sow}

In Chapman University, the court elaborated on the ruling in Main, further extending the scope of FCA liability. In Chapman University, private individuals brought a qui tam action under the FCA alleging that their former employer, Chapman University, made fraudulent assertions regarding its eligi-

162. Id. at 916 .

163. Id.

164. Id. ("The University 'uses' its phase-one application [containing the falsehood] (and the resulting certification of eligibility) when it makes (or 'causes' a student to make or use) a [falsehood free] phase-two application for payment.").

165. Id.

Given the posture of the litigation, we must assume (as the complaint alleges) that the University (a) knew of the prohibition against paying contingent fees to recruiters, and (b) lied to the Department of Education in order to obtain a certification of eligibility that it could not have obtained had it revealed the truth. These facts imply that the phase-two applications [though truthful] would not have been granted had the truth been told earlier, for all disbursements depended on the phase-one finding that the University was an eligible institution.

Id.

166. Id.

167. Id. ("If a false statement is integral to a causal chain leading to payment, it is irrelevant how the federal bureaucracy has apportioned the statements among layers of paperwork."). 
bility to receive federal subsidies under the Higher Education Act ("HEA"). ${ }^{168}$ In Chapman University, however, the "causal chain leading to payment" $"$ was even more attenuated. ${ }^{170}$ Indeed, the qui tam relator in Chapman asserted that the university "lied to the Western Association of Schools and Colleges ... about meeting accreditation" requirements for certain programs. ${ }^{171}$ Relying on the logic of the Main decision, the relators in Chapman argued that, because Chapman University could not operate certain programs without the accreditation of the Western Association of Schools and Colleges ("WASC"), and because Chapman University enrolled students who received federal subsidies in WASC accredited programs, the knowingly false statements made by Chapman University to WASC constituted the basis for a claim actionable under the FCA. $^{172}$

Chapman University argued that because WASC was a third party private accreditation organization, entirely unrelated to the United States Government, any fraudulent or false statement made to obtain accreditation from the organization could not constitute a link in the chain necessary to establish an actionable claim under the FCA. ${ }^{173}$ Chapman University reasoned that any such statement could not by definition constitute a claim for payment directed to the federal treasury. ${ }^{174}$

168. Chapman, 2006 WL 1562231, at*1.

[R]elators allege that ... [Chapman], incident to requesting and receiving hundreds of millions of dollars in federal ... funding annually [pursuant to the FCA], falsely certified to the United States of America ... that they are in compliance with federal provisions requiring that instruction meet certain minimum clock-hour requirements.

Id.

169. Main, 426 F.3d at 916 (7th Cir. 2005) ("If a false statement is integral to a causal chain leading to payment, it is irrelevant how the federal bureaucracy has apportioned the statements among layers of paperwork.").

170. Chapman, 2006 WL 1562231, at *2.

171. Id.

172. Id. ("Relators contend that Chapman's false certification of the number of hours worked by its faculty and false certification that it provides supervised clinical instructions ... are material and fundamental conditions of payment of government funds for tuition loan and grants ..." from the federal government.).

173. Id.

Chapman contends that ... the documents to which Relators refer are government forms or government contracts that either directly or indirectly require Chapman to follow applicable statutory and regulatory schemes, which require that Chapman is accredited by a regional accreditation authority, such as WASC. Chapman avers that Relators claims fail because state and federal financial tuition assistance does not depend on complete compliance with the guidelines of an accreditation agency, such as WASC, but rather depends only on being accredited by an accreditation agency.

Id.

174. See Id. at *4 (contending that "Relators fail to allege any payment of public money that was supposedly conditioned on a particular report from Chapman to WASC."). 
Chapman University also distinguished Main by pointing out that in Main, the university's receipt of federal subsidies was conditioned upon a statutory regulatory requirement; whereas, Chapman University was subject to no such requirement. ${ }^{175}$ Chapman University's arguments notwithstanding, the district court ruled that under the analytical framework established in Main, Chapman University's "allegedly false certifications to WSAC" constituted the first step in a "two-step fraud purportedly accomplished" by Chapman University. ${ }^{176}$ Thus, in Chapman the FCA was expanded to encompass fraudulent claims made by a private university to a private non-governmental accreditation agency whose accreditation program made it possible for students receiving federal subsidies to attend university classes.

\section{EXPANDED LIABILITY UNDER THE FALSE CLAIMS ACT: IN THE WAKE OF MAIN AND CHAPMAN}

\section{A. Expanded Liability of Universities Generally: Why Hospitals Should Take Note}

In Main and Chapman, the Seventh and Ninth Circuits indicated their willingness to impose liability under the FCA for false certifications of compliance made at any stage of a multi-stage certification process. In Main, false certification of compliance in the first-phase of a statutorily prescribed two-phase accreditation process was sufficient to create a cause of action under the FCA. The court in Chapman expanded the Main decision. Broadly construed, the court in Chapman held that, even if a false certification was not made directly to the federal government or in response to a statutory regulation specifically requiring accreditation by a particular agency, it would be sufficient to create a cause of action under the FCA, as long as it formed a link in a chain of causation ultimately leading to a demand on the federal treasury.

The willingness on the part of the federal courts to extend the scope of FCA liability to false certifications of compliance made in the first phase of a multi-phase certification process will undoubtedly make private colleges and universities more amenable to suit by qui tam relators. However, because the Court in Vermont Agency ruled that private individuals do not have standing to bring qui tam actions against states or state agencies, state universities are really no more vulnerable to qui tam actions in the wake of the Main and Chapman decisions than they were before the cases were decided.

That is not to say, however, that the rulings in Main and Chapman will not increase the vulnerability of state universities to suit under the FCA. Vermont Agency merely stated that private individuals lack standing to sue states

175. Chapman, 2006 WL 1562231 , at *3.

176. Id. at $* 5$. 
and their agencies under the FCA. It did not eliminate the power of the Attorney General to file actions pursuant to the CID provisions of the FCA against state universities. Therefore, even though private individuals are precluded under the FCA from pursuing qui tam actions against state universities, the Attorney General is still free to file equivalent actions under the CID provisions of the FCA as long as the complaint meets the knowledge and pleading requirements prescribed by the Act. Moreover, because the rulings in Main and Chapman broadened the scope of false claims actionable under the FCA, the liability of state institutions to such claims has clearly been increased. Consequently, in the wake of Main and Chapman state universities should make a concerted effort to ensure that they avoid making knowingly false certifications of compliance in any phase of an accreditation process aimed at securing federal subsidies under the HEA.

\section{B. The Expanded Liability of Hospitals with Federally Funded Graduate Medical Education Programs}

The rulings in Main and Chapman were clearly tailored to curtail the ability of state and private universities to receive federal funding if they fail to comply fully with the requirements of any accreditation agency permitted to determine a university's eligibility to receive federal funds at any stage of an accreditation process. As such, the rulings would also seem to dramatically expand the applicability of the FCA to claims brought pursuant to the Act against any teaching hospital that receives federal funding.

Hospitals employing the services of graduate medical residents receive a majority of the funding for their residency programs from the federal government through the Medicare program. Moreover, to receive such funding, hospitals with GME programs must be accredited by the ACGME. Accreditation by the ACGME is premised upon compliance with, among other things, the duty hour limitations imposed on Residents by the ACGME. Prior to the holdings in Main and Chapman, it could be persuasively argued that a hospital's failure to comply with the duty hour limitations of the ACGME, a private accreditation agency, did not constitute behavior implying liability under the FCA. Under the logic of the holdings in Main and Chapman, however, hospitals that knowingly fail to comply with the ACGME's duty hour limitations would probably be liable under the FCA for defrauding the federal treasury.

\section{Hospital Liability Under the False Claims Act: A Statute Reinterpreted}

Hospital liability under the FCA for violations of resident duty hour standard violations would be premised upon existing federal law as interpreted by the federal courts. ${ }^{177}$ As such, federal legislation governing the duty hours of

177. United States ex rel. Raymer v. Univ. of Chi. Hosp., No. 03 C 806, 2006 U.S. Dist. 
medical residents is no longer necessary. Under the federal judiciaries rulings in Main and Chapman, strict compliance with the ACGME duty hour standards adopted by OSHA is required of any hospital receiving federal funding for its GME program. Furthermore, given the applicability of the FCA, enforcement of the ACGME's duty hour standards in hospitals that refuse to comply is no longer problematic. Residents, acting as qui tam relators, are free to bring claims against any public or private hospital that knowingly fails to enforce the duty hour standards. Even hospitals associated with state universities would be amenable to suit brought by the Attorney General pursuant to the CID provisions of the FCA.

\section{Whistleblower Protections for Sleepy Residents: A Dream Come True}

In addition to facilitating enforcement of the ACGME duty hour standards, the federal judiciary's expansion of the FCA's applicability in Main and Chapman also ensures that Residents, acting as qui tam relators, could enjoy all of the whistleblower protections afforded by the FCA. In the wake of these rulings, many of the practical impediments that formerly curtailed the efforts of Resident duty hour reformers and patient advocacy groups have theoretically ceased to exist.

Residents, though still subject to the challenges imposed by the traditional master-apprentice paradigm of medical education, may now engage in the selfreporting essential to the enforcement of the ACGME's Resident duty hour standards. If Residents report duty hour violations, file a qui tam action seeking enforcement of the duty hour standards, and are discharged or harassed as a result; they are free under the FCA to bring suit in federal court for retaliatory action. Moreover, assuming that the FCA is applicable to ACGME duty hour violations, self-reporting Residents can retain relative anonymity; thereby, avoiding the need to face a no win situation in which compelling hospital compliance with duty hour standards will most likely result in injury to their nascent careers.

Furthermore, hospitals with GME programs found guilty of violating the ACGME Resident duty hour standards, while receiving federal subsidies, would likely be found guilty of defrauding the federal treasury. Theoretically, Resident whistleblowers, patient advocacy groups, and members of the AMSA, acting as qui tam relators, would be eligible to receive a sizable percentage of the treble damages and civil penalties likely to be levied against any hospital found guilty of violating the standards. ${ }^{178}$ Moreover, the Attorney General would be independently eligible to prosecute offending hospitals under the FCA.

LEXIS 7943 (7th Cir. Feb. 28, 2006) (demonstrating the willingness of the federal courts to apply the Main standard of enhanced liability to claims filed against federally funded hospitals generally).

178. 31 U.S.C. $\S 3729(a)(1)-(7)$. 


\section{CONCLUSION}

The Resident duty hour controversy has long been a polarizing issue in the American medical community. Rooted as it is in the very bedrock of the master-apprentice paradigm of medical education, the Resident duty hour question has effectively defied intervention by legislatures, Residents, the AMSA, and private individuals. The obdurate stance adopted by medical educators and medical professionals within the AMA and ACGME has rendered ineffective the Resident duty hour standards adopted by OSHA. It would seem, therefore, that Resident duty hour reform is unlikely to take root naturally in the United States, despite the will of the general population.

Recent decisions in the Seventh and Ninth Circuits, however, have dramatically altered the landscape of the Resident duty hour controversy. By making the FCA applicable in any situation where federal funding is procured through knowingly fraudulent means, regardless of attenuation in the chain of causation leading to the procurement, the precedent set by the courts in Main and Chapman changed the very nature of the debate. Prior to these decisions, proponents of Resident duty hour reform had few tools suited to the task of bringing about change in the medical community's perception of limited Resident duty hours. In effect reformers efforts were largely ignored or marginalized by medical practitioners' intent on preserving the stasis quo. The precedent set by Main and Chapman has provided Residents and other interested parties with the leverage necessary to effectively challenge hospitals and supervising medical practitioners who refuse to adhere to the Resident duty hour standards promulgated by the ACGME. These standards, if enforced, would ensure that Residents are not required to provide potentially life saving medical care while suffering from chronic sleep deprivation.

Thus, given the precedent set in Main and Chapman, the question is no longer if private and state run hospitals will comply with the ACGME's Resident duty hour standards, but when they elect will do so. Indeed, if hospital managers, medical educators, and representatives of the ACGME choose not to comply with the standards, they may face large financial penalties under the treble damages provision of the FCA. Thus, it can be presumed that, even though the American medical community has been slower than its counterparts in other nations to adopt Resident duty hour reforms likely to benefit Residents and patients, it will find ample reason to adopt such reforms if doing so will avoid stiff financial penalties. The motivation behind the compliance notwithstanding, it is the Residents and patients who will reap the greatest reward from the application of the FCA to the Resident duty hour controversy. 
